\title{
HIBRIDITY OF THE CHARACTERS IN MY SON THE FANATIC SHORT STORY BY HANIEF KURESHI
}

\author{
Michelle Intan Goh Rumengan Waworuntu ${ }^{1}$ \\ Universitas Putera Batam (UPB), Batam, Indonesia \\ pb151210091@upbatam.ac.id ${ }^{1}$ \\ Tomi Arianto ${ }^{2}$ \\ Universitas Putera Batam (UPB), Batam, Indonesia \\ tomi.arianto@puterabatam.ac.id ${ }^{2}$
}

\begin{abstract}
This study aimed to reveal the forms of hybridity as a result of the existence of postcolonial cultural contact with the construction of a colonial form. Researchers revealed the hybridity represented by the characters Parvez and Ali in My Son the Fanatic Short Story by Hanief Kureshi. This study used the Postcolonialism approach in the hybridity concept of Homi K Bhabha. According to. Bhabha (1994) Hybridity is a cross between two different cultures in a tangent interaction. In this case, hybridity is not only seen as a fusion of culture but also cultural products placed in social and historical space under postcolonialism which are part of the imposition of colonial power relations. The qualitative descriptive method was used in this study because of its essence in descriptive text analysis in predetermined literary works. The results of this study indicated that there are two forms of hybridity representation in this study. First, the character of mimicry in the sense of ambiguity and contradictory character as a discourse of cultural devotion due to the colonial construction that was formed. Mimicry is represented by the character Parvez in the story. Second, the ambivalence represented by his son named Ali. Ali was aware of the colonial discriminatory against culture so he resisted the construction but on the other hand, he did not know what identity he should hold.
\end{abstract}

Keyword: hybridity, mimicry, ambivalence, and postcolonial construction

\section{INTRODUCTION}

Postcolonial showed that what is called the "third world" is not uniform. There is heterogeneity both because of the region, the people, and the culture. It also showed that there was certain resistance from East to West. One very well-known form is what is called "subaltern" by Spivak (1990). In essence, postcolonial provides a framework for destabilizing that there are inherent assumptions inherent in Western thought that have always claimed to be the highest and universal truths. The postcolonial theory was developed in a grounded manner by raising various real evidence of the results of colonialism, both physically, politically and culturally (Said 1978).
The aim of developing postcolonial theory is to counter the remnants of the impact of colonialism on the knowledge including on the cultural side. Postcolonial is oriented towards the realization of a new world relations system in the future. Postcolonial is a theory that assumes and at the same time explores fundamental differences between colonial and colonial states in addressing the direction of their cultural development (Huntington 2001). This theory is applied to study the cultural character that was born, especially in third world countries or ex-colonial countries in the decade after colonialism ended.

Postcolonial theory according to Budiawan (2010) can be said as a theory that can be used as an analytical tool to 
challenge colonialism practices that are continuing or a new form of colonialism that has given birth to a life filled with racism, unbalanced power relations, subaltern culture, hybridity, and creationism is not through war propaganda and physical violence, but is dialectically through consciousness or ideas. Makaryk in Faruk (2007) defines postcolonial as a collection of theoretical and critical strategies that have assumptions to question the position of colonial and post-colonial subjects. Similar to Makaryk, Ratna (2008) concludes that what is meant by postcolonialism are ways used to analyze various cultural phenomena, such as: history, politics, economics, literature, and various other documents, which occur in former colony countries Modern Europe. In other words, postcolonial as a tool or tool of criticism that sees how the cultural, social and economic joints in which there are postcolonial subjects.

Bhabha (1994) on the other hand criticized the binary opposition model of colonial relations as suggested by Edward Said and other orientalist concepts. Said focuses on colonial discourse, while Fanon on colonial discourse. Both consider that the position between invaders and colonizers is integrated and stable, also different and contradictory to each other, while Bhabha's concepts assert that neither the colonizer nor the colonized are independent of each other. According to Bhabha in Mashlihatin (2013) between invaders and colonized there is an "intermediate space" that allows the two to interact. Between the two is a loose space for resistance.

The loose space between these then raises the interaction between invaders and colonized and then forms a hybrid identity. Hybridity according to Day \& Foulcher (2008) is a term used to refer to interactions between different forms of culture that can result in the formation of new cultures and identities with their history and textual manifestations. This hybridity strategy can be pursued using mimicry. Mimicry is a mottled reproduction of colonial subjectivity in an 'impure' colonial environment, displaced from its origins and reconfigured in the special sensibility and anxiety of colonialism. The hybrid identity of this act of mimicry was never truly controlled or controlled by the colonial authorities because there was ambivalence in the colonial discourse. For Bhabha, the colonial presence is always ambivalent, divided between presenting itself as authentic and authoritative with its articulation which shows repetition and difference Mishra (2007).

One story that presents the phenomena of hybridity, mimicry, and hybridity is reflected through the story of My Son The Fanatic Short by Hanief Kureshi. This short story tells the life of a Pakistan immigrant who lived in England. Parvez, a father who works as a taxi driver, decided to leave Pakistan and migrate to England to get a decent life. His traumatic childhood was the result of a wrong education system, especially religious education which was so hard that it gave rise to a different perception of religious authentication. He regards the Muslim religion which he held as a representation of eastern countries which is thick with violence, inclusive, and does not respect his freedom. He then gained this freedom in London as a state system that he exalted. During his 40 years in England, he worked as a taxi driver and hung out with prostitutes. Instead, his son named Ali, whom he hoped could continue the dream of success and wealth in Britain, changed direction. Ali has since recognized the teachings of the religion he has endeavored to change the way he thinks and acts. He opposed all the 
habits of his father who came out of eastern culture and away from religion. The conflict between the two characters' perceptions is what gave rise to the postcolonial analysis in this study.

The practice of colonialism does not have to be imperialism as in the past colonial period. The occupation until now is still realized in the way of thinking and acting in the former colonial community. This is addressed in the concepts of hybridity, mimicry and ambivalence described above. My Son The Fanatic's short story is thick with the representation of the hybridity's cultural identity. By using the Postcolonial approach, the researcher aims to express hybridity in the form of mimicry and ambivalence to the characters in the story. The identity can be seen from the actions and utterances conveyed by the characters in the storyline.

\section{Literature Review}

According to Gilbert (1997) in his book entitled Postcolonial Theory: Contexts, Practices, Politics, he explained that the Postcolonial Theory that was born in the second half of the 20th century is often referred to as a deconstructive method of dualist (binary) thinking models, even though those who claim to be experts with a postcolonial perspective are not really able to escape this snare. The dualist thinking model that settles in Western science, especially in the study of Eastern problems (orientalism), always places the position of the West, the invaders, self, observers, and subjects to have a superior position compared to the East. East is colonized, outsiders, objects, are told, and so on. Modern Westerners feel they are different from Easterners who are seen as irrational, emotional, and less civilized (for example in politics referred to as "Eastern despotic").
Postcolonial theory is a critical theory as one form of a group of postmodern theories. Postcolonial shows that what is called the "third world" is not uniform. There is heterogeneity both because of the region, the people, and the culture. He also showed that there was certain resistance from East to West. One very well-known form is what is called "subaltern" by Spivak. In essence, the post-colonial provides a framework for destabilizing that there are inherent assumptions inherent in Western thought that have always claimed to be the highest and universal truths. The postcolonial theory was developed in a grounded manner by raising various real evidence of the results of colonialism, both physically, politically and culturally.

The aim of developing postcolonial theory is to counter the remnants of the impact of colonialism on the knowledge including on the cultural side. Postcolonial is oriented towards the realization of a new world relations system in the future. Postcolonial is a theory that assumes and at the same time explores fundamental differences between colonizing and colonized countries in responding to the direction of their cultural development. This theory is applied to study the cultural character that was born, especially in third world countries or excolonial countries in the decades after colonialism ended.

2.1 Bhabha's hybridity theory

Hybridity is the formation of a new culture in the contact zone created by the existence of colonialism. As in horticulture, the term refers to the mixing of two species to create a third form, namely hybrid species. The term hybridity is associated with the work of Bhabha which analyzes the relationship of invaders and colonizers, especially their dependence on each other and the mutual construction of their subjectivity 
(mimicry and ambivalence). Bhabha (1994) reasoned that all cultural statements and systems are formed in the space he calls the Third Space of Enunciation.

Cultural identity emerges in contradictory and ambivalent spaces which Bhabha calls the "purity" of a hierarchy of culture that cannot be maintained. For Bhabha, recognition of the ambivalence space of cultural identity can help overcome the exoticism of cultural diversity to support the recognition of hybridity authority in itself in places that have cultural differences. Ultimately, the cultural authority will result in inferior cultural construction and superior culture. The colonialists will try to construct the thought of the colonized by injecting the assumption that the culture they carry is in a higher hierarchy than the culture of the colonized. Some of the colonized people whose thought was successfully constructed would agree with the assumption that the culture of the colonizers was superior to the culture of the colonized. They will then try to imitate the culture of the invaders, such as through lifestyle and appearance to elevate their status, is approaching the status of the colonizers. This action is then called mimicry.

2.2 Mimicry theory

Mimicry according to Bhabha (1984) it is a cultural process that provides an opportunity for the agency of the colonial subject to enter into the dominant power and at the same time play in it by showing subjectivity that resembles the colonizer but is not entirely the same. Mimicry actions carried out by the colonized is one way they feel the superiority of the invaders. By imitating, the colonized people feel that they have more power and are in a higher position than other colonized people.

\subsection{Ambivalence theory}

Ambivalence according to Young (1995) is an attraction as well as an aversion to a particular object, person, or action. Bhabha even adopted the term in the colonial discourse as acceptance and rejection that characterizes the relationship between invaders and colonized; Ambivalence relations arise due to the behavior of colonial subjects who are not only and completely opposed to colonialism; colonial subjects, on the one hand, received power, but on the other they resisted. That relationship is called ambivalent because the colonized subject never really opposes the invaders. Ambivalence, in this case, states that involvement and resistance are in a fluctuating relationship in colonial matters. Ambivalence according to Bhabha (1984) also shows that colonial discourse is related to colonized subjects who can exploit and / or educate at the same time. Bhabha points out that the ambivalence of the colonial discourse also had implications for both the colonizers and the colonized. This concept is related to hybridity. That is due to the ambivalence of decentralizing authority (authority), namely from the position of power so that hybridization or change can also occur when dealing with other cultures in the colonial context. Engagement with the culture of the colonized will lead to ambivalence. Therefore, according to Bhabha (1984) monolithic domination is not possible.

If the act of mimicry represents the attitude of agreeing to the idea of the superiority of the colonialists, it is the act of resistance that represents the attitude of rejecting the idea. Resistance was carried out to reject all forms of colonial practice, including submission to the idea of the superiority of the colonizers. What needs to be emphasized in this statement is that the 
colonizers meant not only the Europeans or the Dutch who were then in control of the Dutch East Indies, but all forms of colonialism, such as cultural traditions, patriarchal systems, and racism.

\subsection{Previous Study}

Research that analyzed the short story of My Son The Fanatic by Hanief Kureishi was written in several journals. First, a journal written by Rokhman (2015) entitled British Immigrant's Father and Son: Psychoanalysing Kureishi's My Son The Fanatic. This journal uses Freud's approach to the concepts of consciousness, unconsciousness, and identification. This research shows that parvez dreams represent a father's subconscious representation of his child. Instead, Ali's identification of his father failed so he sought a father figure in God in Islamic teachings.

The second research was written by Rizvi (2015) in his journal entitled Irony, identity and Islam: rejection and acceptance in Hanif Kureishi's "My Son the Fanatic". Rizki in his journal explained that the short story of My Son The Fanatic shows there is an irony formed by the western world which subsequently leads to propaganda against the image of Islam. These ideological differences then lead to conflict and disharmony between Parvez and Ali in the story. This journal reveals much about the problems of identity and ideological differences found in Islam towards a Western culture that leads to the post-colonial concept in the short story.

The third journal was written by Ali (2018) entitled Identity Crisis in Hanif Kureshi's My Son the Fanatic. In his journal, he explained that Hanif Kureshi's story shows a form of identity search carried out by Asians in European countries as a representation of Western culture. He also explained that this story revealed the identity of eastern people who were assimilated by the dominant culture so that they tended to imitate, imitate, and even adopt this identity without thinking. The colonial subject reconstructed itself in all social domains of traditions, habits, patterns of behavior, and language to assimilate in British society.

The fourth journal was written by Arianto \& Ambalegin (2019) titled Indoctrination Against Women in "The Lowland" by Jhumpa Lahiri. Arianto raised the character of calcuta women who live as subalterns. Women are indoctrinated by the culture and morals of society to become submissive, domestic, purity, and piety. On the other hand, the woman also resisted the local culture because of the ideological knowledge and understanding she got from studies in the west. This journal does not specifically address postcolonial but rather inspires enough as a form of resistance to conservative dogmas that construct eastern thought..

\section{Research Method}

The method used in this research is a qualitative method. According to Bogdan and Taylor in Moleong (2001) define qualitative methods as research procedures that produce data Descriptive form of written words or verbally from people and behaviors that are can be observed. Next, there are two stages in this research. The first stage is the data collection stage. Data collection according to Faruk (2012) is a set of ways or technique which is an extension of the human senses because of its purpose to gather empirical facts related to the research problem.

The collection of facts that will be used in the next stage, namely the analysis phase, is done after reading the Short Story entitled My Son The Fanatic. In the analysis phase, a qualitative method is used, namely the short story analysis conducted in 
accordance with the theory postcolonialism. My Son The Fanatic Short Story is identified by looking for elements related to hybridity. In the short story, Parvez and Ali's figures have different forms of hybridity representation in each role. Furthermore, the data analysis stage is carried out with a work system that contains a variety of relevant and representative written sources. The data used include basic and supporting data. The main data in the form of short story entitled My Son The Fanatic, while supporting data in the form of literature references and postcolonial theory. The research method used is qualitative.

\section{Result and Discussion}

The practice of imperialist colonialism is no longer valid today. Whatever form of physical violence the colonization of social discrimination is outspoken will be automatically opposed by the world because it is not by the principle of humanity. Colonization in the framework of the construction of superiority to the mentality of postcolonial societies still applies in different dimensions. The practice presents a construction of thought which unconsciously permeates the thoughts of the ex-colonial community. This conception then provides a postcolonialist analysis space that is fundamental to the way of thinking and inferior mentality and increasingly supports the construction of colonial superiority.

The short story My Son The Fanatic presents two different characters in terms of hybridity or cross-culture of eastern communities living in Europe. This was represented through the Parvez Punjabi family, a Pakistani family living in England. Like other immigrant communities, Parvez is a Pakistani who tries to combine fate to England to get a decent life. For many years, Parvez lived in England as a taxi driver and brought his son named Ali. Ali, he was educated to follow the pattern of western life and take his education from Accounting to lectures. Both conflicts occur when there is an identity clash that questions who they are. It is this identity conflict that will later reveal hybrid identities (Ambivalence and Mimicry) as well as resistance to cultures that they recognize as constructionist.

Hybridity is a cross culture of two cultures that intersect and give birth to a new culture. The difference here is that hybridity is not just a cultural mix but also cultural products which then impose colonial forms of power in the way of thinking and acting. This is shown from the opportunity given by Britain to open up opportunities for former colonies to be able to migrate in the UK. Immigration to Europe has a long history after World War II. The trend which views that Europe has a decent source of living then triggers a massive migration of countries in the world such as Mexico, India, Bangladesh, Jamaica, including Pakistan. The Parvez family is a representation of the Pakistani community who pitted their fortune to migrate to England.

That space of thinking then opened the opportunity for eastern people to feel the superiority of Western culture. The conception of thinking that the west is a country that is more civilized, free, educated, and great is increasingly affirming the superiority of the west. On the other hand they empathize with their own culture which they label as inferior. Easterners then try to become westernized by following the pattern of life. On the other hand, the West is playing with the space by providing opportunities while closing itself inclusively. In the sense that the east feels himself west but he is not accepted in the West himself. This is 
also felt by Parves in his short story quote:

Parvez has been a taxi driver for twenty years. Half that time he'd working as a firm. Like him. Most of others driver are Punjabis. They prefer to work at night, the reads were clearer and many is better (Kureishi, 1994).

Like other immigrant workers, for many years they complained about their fate in England without any talent. Just relying on how they think they are ready to complain by working in any field. In fact, Parvez has never been able to get a decent job despite his adherence to Western ways of life and thinking.

\subsection{Mimicry}

The product of cultural crossing which was then conceptualized by Bhabha as a hybridity then gave birth to a Mimicry identity. Mimicry is a mottled reproduction of colonial subjectivity in an 'impure' colonial environment, displaced from its origins and reconfigured in the special sensibility and anxiety of colonialism. The hybrid identity of this act of mimicry was never truly controlled or could be controlled by the colonial authority.

The form of mimicry is to glorify western culture when colonial discourse provides space for colonies to share in the sense of superiority built. Thus the hierarchy of western superiority is increasingly confirmed by the cultural devotion. In the short story My Son the Fanatic by Kureishi, the manifestation of the identity of the mimicry is clearly seen through the character Parvez. Not without reason, Parvez experienced disappointment over his true identity because he felt that the culture he had been living in Pakistan was not in accordance with his principles and way of thinking. This can be seen in the following quote:

Parvez had grown up in Lahore where all the boys had been taught Koran. To stop him falling asleep when he studied, The Maulvi had attached a piece of string to the ceiling and tied it to Parvez hair's, so that if his head fell forward, he would instantly awake. (Kureishi, 1994)

The above quote shows that Parvez suffered childhood trauma when he was studying religion in his village called Lahore. The wrong learning system then instills a wrong paradigm for parvez about understanding religion. He considers that the religion he professes to be conservative, rigid, and restrictive. That is why Parvez experienced disappointment over the past and increasingly farther with the teachings he once worked on. On the other hand, this form of disappointment was given to him when he was in England. He knows the prohibitions of religious teachings that he must avoid but consciously he continues to do. This is also seen in the following short story excerpt:

Ali then reminded Parvez that he had ordered his own wife to cook pork sausages, saying to her, You're not in the village now, This is England. We have to fit in. (Kureishi, 1994).

The quote above also shows the actions taken by Parvez while in England. He was aware that Alcohol and Pork were forbidden by his religion. Parvez continues to consume these foods and drinks consciously and says "You are not in village now". The statement not only explained parvez's lack of understanding of religious teachings. $\mathrm{He}$ was well acquainted with the laws he had learned from childhood. On the contrary, hybrid ideology and thinking then change the way he thinks and the actions he takes. The cross form of culture that forms the pattern of thinking then constructs the paradigm that western culture is a culture that is 
superior to the culture it has. $\mathrm{He}$ consumed the food as a form of cultural adoption and an attempt to enter the colonial superiority space. On the other hand, the way of thinking that considers religious efforts that forbid consuming food and drink is a conception that is built that eastern culture is inferior culture. This is what is always reflected in the daily life of Parvez while in England. He seeks to emulate Western behavior and culture and to discredit his native culture as an inferior culture. In other words, the mimicry identity products experienced by Parvez increasingly reinforce western superiority and recognize eastern inferiority. While the west in this case toying with the space while still isolating itself.

\subsection{Ambivalence}

Knowledge of colonial discourse that shapes colonial subjects is knowledge of the structure of colonial society itself. Discourse always works in its apparatus system. In the apparatus system, the subject is formed. The intended discourse is the construction of binary opposition about the west and east or about superiority and inferiority. The discourse is rooted in colonial ways of thinking and behaving as hybrid nature which gives birth to mimicry and ambivalence on one's cultural identity. The apparatus system that works is represented by various "the productive of knowledge" such as educational, financial, advertising, and other knowledge production institutions. Discourse about the face, glory, glamor of Europe is also revealed in the story of My Son the Fanatic as the implications of post-colonial construction space. This can be seen from the dreams of Parvez to throw themselves into a European country for the hope of getting a decent life. This then disappears when the dreams fail when he sees his child farther from his expectations. This phenomenon can be seen from the following quote:

I feel as if I've lost my son. Parvez told to Bettina. I can't bear to be looked at as If I'm Criminal. I've decided what to do. (Kureishi, 1994).

The narrative of Ali's change of attitude and way of thinking made his own dilemma from his father. Parvez has prepared his child to achieve his future hopes. He wants his children to study well, get a bachelor's degree, work, get married and live happily. Instead, Ali decided to drop out of school, leave his education, throw away all of his music equipment, leave his favorite playboy magazine, and break up with his white girlfriend. All the attitude of change shown by Ali is a form of resistance to the ideological awareness he has been living up to. Parvez feels himself increasingly distant with his child. This means that Parvez's dreams vanished with a change in Parvez's attitude.

Parvez's dream is an unconscious representation that shows Parvez's ambivalent identity. He was so fascinated by Britain's future offer for European immigrants to be able to improve life and the economy. On the other hand, the dream could not be achieved because of ideological conflicts and attitude changes made by their children. In this case, Parvez felt that he had followed all Western culture, but on the other hand he failed to enter the empire formed by the west itself. The disappointment experienced by Parvez is a form of failure of the dream he wants to achieve.

Not only that, parvez's efforts to persuade their children to be ideologically correct. This is indicated in the following quote:

What do you mean by "make the best of it? Asked the boy 
"well". Said Parvez. "For start....

You should enjoy yourself. Yes.

Enjoy your self without hurting

others. (Kureishi, 1994).

The above quote also reveals his father's mindset about the world. This debate took place when Ali asked what we should do when many easterners were treated inferiorly; many were starving, poverty while Europeans enjoyed their superiority because of a deep-rooted and structured capitalism system. Parvez responded with "just enjoy yourself without hurting others". This further shows the striped identity of Parvez. He realized about the nation and its origin. On the other hand he does not care about the nationality. He only wanted to imitate western culture so he could enter the circle. Whereas it cannot be separated from its eastern form and is not found in the western constructional circle.

The real ambivalence also happened to Ali. Ali was very aware of the discriminatory behavior of the west towards the east. He was aware of the inferior construction formed by the west against immigrants. He also realized that western culture was not his identity from the quote "the was a sink of hypocrites, adulteress, homosexuals, drug takers, and prostitutes". But in reality, Ali's way of thinking also showed that his mind was also constructed. Indirectly, Ali has recognized the existence of a superiorinferior / west and east dichotomy. Ali's statement further confirms that the perception of the west as superior through the conception of the claim image that is built in his statement, as well as the attitude of ambivalence that he showed. Ali wants to get out of the cultural identity he currently lives. However, Ali also did not know the eastern identity which he had to go through. A third identity arises when he recognizes the teachings he embraces as eastern representation. The perception of
Muslim teachings as eastern identity obscures Ali's thinking about resistance to the construction of identity. Ali increasingly showed that he too experienced ambivalence.

\subsection{Resistance}

The practice of colonialism gave rise to the construction of colonized groups and colonialist groups. The invaders always held more power over the colonized. The colonizers not only tried to master the physical and material occupation of the colonized, but also tried to master the construction of the thought of the colonized. Mastery or more accurately called the conquest of the construction of the thought of the colonized is said to be successful if the colonizers have been able to instill ideas in the minds of the colonized, namely that the colonizers are superior to the colonized, especially in terms of culture.

The cultivation of the idea of superiority of the invaders was very important in the practice of colonialism. If the colonized people have agreed to the ideas implanted in them, the process of colonialism will be more easily carried out. Some of the colonized people who agree with the idea of superiority of the invaders are more likely to carry out acts of mimicry. The action was simply done so that the colonized people could share in the same power and position as the colonialists.

If mimicry is an attitude of agreeing to the superiority of the invaders, in this case Western culture is represented. The act of resistance is representative of the resistance to the constructionist idea. Resistance is done to reject all practices of inculcation of the idea of western superiority, including submission to the idea of superiority. This is manifested in the form of Ali's thinking awareness through the following quote conversation: 
The Problem is this, the boy said.

He leaned across the table. For the first time that night his eyes were alive. "You are implicated in western civilization"

The western materialist hate $\mathrm{u}$, Ali said. Papa, how can you love something which hates you." (Kureishi, 1994).

Ali's decision to abandon all of his past habits was a form of resistance to the idea of Western superiority. The resistance is also represented by attitudes that are contrary to the thoughts and ways of thinking of his father. The resistance Ali showed was more in the awareness of the colonialist construction formed in his father's mind. He wants to get out of the construction and find an identity that rejects all Western ideas. In the narration, Ali is told to refuse to consume foods that he considers forbidden, to abandon the habits of hedonism, until he decides to leave the education he is currently taking.

The peak of the conflict from Ali and Parvez ended with acts of violence committed by Parvez as an accumulation of disappointment over the achievement of hopes and dreams for his child. When he was hit Ali also showed his resistance in a paradigmatic way, not by hitting his father again. Ali's last statement saying "who is the fanatic now" slapped his father's prejudice that Ali was caught up in teachings that made him conservative and inclusive. On the contrary, Ali shows that his father is fanatical about westernized thinking and forgets his identity as an eastern person. He also wanted to show that his father was experiencing an acute postcolonial by adopting all western culture to be included in the circle of superiority.

\section{CONCLUSION}

The practice of postcolonialism is clearly seen in the short story of My
Son the Fanatic by Hanif Kureishi. This analysis emphasizes the phenomenon of hybridity and character resistance in this story. Hybridity is demonstrated in two mimicry identity products and ambivalence. The form of ambivalence refers to the paradigm of postcolonial thinking that highly glorifies western ideas. This paradigm of thinking is formed as a form of cultural crossing deliberately formed by the west within a colonial framework. This is shown by the character of Parvez who is very oriented towards the West through his attitudes, actions, and habits. Like the concept of ambivalence, Western superiority plays in the space he gives to colonized countries by providing opportunities as well as closing themselves. The same thing happened to Parvez who felt he was so westernized but at all he was unable and not accepted in the circle. The impact of ambivalence then gave rise to a third role called mimicry. Ali on one hand acts as a resistance in the form of his awareness to reject Bara's ideas. On the other hand, Ali was still trapped in identity because he was in a position that did not recognize his eastern identity. Because of that, he claimed that the teachings of Islam that he was working on as an expression of eastern identity. The impact was that Ali was also in the third room creating his own identity. He rejected Western ideas and was also unable to recognize his eastern cultural form.

\section{REFERENCES}

Ali, H., \& Ahmad, N. (2018). Identity Crisis in Hanif Kureshi's My Son the Fanatic. 7(2), 285-291.

Arianto, T., \& Ambalegin. (2019). Indoctrination Against Women in "The Lowland" by Jhumpa Lahiri. OKARA: Jurnal Bahasa Dan Sastra, 12(2), 153-166. https://doi.org/http://dx.doi.org/10. 
19105/ojbs.v12i2.1935.

Bhabha, H. K. (1984). Of Mimicry and Man: The Ambivalence of Colonial Discourse. Discipleship: A Special Issue on Psychoanalysis, 28, 125133. https://doi.org/10.2307/778467

Bhabha, H. K. (1994). The location of culture. London: Routledge.

Budiawan. (2010). Ambivalensi: PostKolonialisme membedah musik sampai agama di Indoensia. Yogyakaarta: Jalasutra.

Day, T., \& Foulcher. (2008). Bahasan Kolonial dalam Sastra Indonesia Modern Catatan Pendahuluan. Jakarta: Yayasan Obor Indonesia.

Faruk. (2007). Belenggu PascaKolonial, Hegemoni dan Resistensi dalam Sastra Indonesia. Yogyakaarta: Pustaka Pelajar.

Faruk. (2012). Metode Penelitian Sastra Sebuah Penjelajahan Awal. Yogyakarta: Pustaka Pelajar.

Gilbert, B. M. (1997). Postcolonial Theory: Contexts, Practices, Politics. London: Verso.

Huntington, S. P. (2001). Benturan antar Peradaban. Yogyakaarta: Qalam.

Kureishi, H. (1994). My Son The Fanatic. boston: The New Yorker.

Mashlihatin, A. (2013). Teori pascakolonialisme homi k. bhabha: ontologi dan epistemologinya.

Mishra, V. (2007). The Literature of the Indian Diaspora Theorizing the Diasporic Imaginary. London: Routledge.

Moleong, L. J. (2017). Metodologi Penelitian Kualitatif (37th ed.). Bandung: PT Remaja Rosdakarya.

Ratna, N. K. (2008). Postkolonialisme Indonesia. Yogyakaarta: Pustaka Pelajar.

Rizvi, A. (2015). berjudul Irony, identity and islam: rejection and acceptance in hanif kureishi's "My Son the Fanatic." International Journal of
English Language, Literature And Translation Studies (IJELR), 2(3), 214-217.

https://doi.org/https://doi.org/10.33 329/ijelr

Rokhman, M. A. (2015). British Immigrant's Father and Son: Psychoanalysing Kureishi's My Son The Fanatic. Humaniora, 17(2), 204-211. https://doi.org/http://dx.doi.org/10. 22146/jh.v17i2.846.

Said, E. (1978). Orientalism. New York: Pantheon.

Spivak, G. C. (1990). Can the Subaltern Speak? Colombia: Columbia University Press.

Young, R. J. C. (1995). Colonial Desire: Hybridity in Theory, Culture and Race. London and New York: Routledge. 
